\title{
Repensar o ensino da língua - abordagem comunicativa
}

\author{
Estela Pinto Ribeiro Lamas \\ Universidade Metodista Unida de Moçambique
}

\begin{abstract}
Resumo
Colocamos em realce questões ligadas ao ensino da língua, revendo enfoques que, ao longo dos tempos, têm sido realizados, ora enfatizando o destaque dado à forma como a língua é abordada enquanto objecto de estudo, ora destacando o papel da língua na educação, o seu contributo para a construção do(s) saber(es) em diferentes áreas do conhecimento. Ao fazê-lo, retomamos a dimensão ontológica da língua, que permite ao indivíduo ser, exprimindo os seus pensamentos e sentimentos, comunicar/interagir, entrando em contacto com o(s) outro(s) e com o mundo, modelizando-o, e construir conhecimento. Destacamos a abordagem comunicativa no ensino da língua.

Palavras-chave: aprendizagem da língua, aprendizagem experiencial, abordagem holística, autonomia
\end{abstract}

\section{Repensar o ensino da língua}

Repensar o ensino da língua implica focarmo-nos em questões que nem sempre têm sido encaradas numa relação dialógica: a língua na educação / a língua para a educação. Não apenas neste artigo, mas em todos os que integram este simpósio, são questionados aspetos que estão subjacentes a esta relação - a língua encarada como mediadora da comunicação/socialização, como instrumento para a construção do(s) conhecimento(s), mas também como objecto de estudo.

Cientes de que a realidade passa a existir para o ser humano, quando ele a nomeia, a língua está sempre em destaque, na problematização que fazemos; uma vez que está em causa, neste simpósio, a comunicação, a interação a construção do conhecimento, que o ser realiza, através do uso da língua, procuramos ter presente que

qualquer indivíduo, ao mostrar-se interessado num texto, fá-lo motivado pelo seu conteúdo (...) para apreender esse conteúdo, ele precisa de dominar os mecanismos da língua em que está escrito - os mecanismos que permitem a expressão das ideias, isto é, o comunicar das ideias que constituem o conteúdo que o atraiu. (Lamas, 1992, p.136)

Tendo como princípio que a educação implica a vivência da interculturalidade e a inclusão social, o alvo é identificar o papel que a língua desempenha na descoberta do eu, na vivência do eu com o outro, na construção colaborativa da (inter)culturalidade, na sua aceitação e consolidação, para que seja viável comunicar, agir e (con)viver em sociedade.

A língua é e será sempre instrumento de comunicação e objecto de estudo, sempre renovável e plausível de aprimoramento. Contudo, na abordagem da língua, em contexto escolar/académico, põe-se muitas vezes o problema da separação destas duas componentes - a língua como mediadora e a língua como objecto de estudo. Corre-se, assim, o risco de separar a língua per se, da língua que está no centro da experiência vivida pelo aprendiz.

O ensino da língua pressupõe a realização linguística do indivíduo e, consequentemente, uma íntima relação da língua enquanto objecto de estudo e da língua enquanto objecto de comunicação. Contemplar estas duas perspectivas é a nossa preocupação; esta é a questão posta em evidência nos diferentes contributos que integram este simpósio.

\section{A dimensão ontológica da língua}

Ontologicamente, a comunicação tem por fim a participação do ser na vida, na sua relação existencial que o discurso institui. Nessa relação, a palavra suscita no indivíduo a atenção ao mundo e aos seres que o cercam; podemos mesmo dizer que o força a integrar-se num determinado contexto.

A língua assume a função pragmática de orientar o ser no mundo; ela é a marca existencial do ser, no contexto em que se vê envolvido, num mundo que ele tenta captar e com o qual tenta comunicar; ela é um meio através do qual essa comunicação é possível e resulta da concretização da relação existencial do ser com o mundo; ela confere existência ao sujeito falante, potenciando a organização/manifestação dos seus pensamentos, viabilizando a expressão dos sentimentos que vivencia, permitindo-lhe interagir e relacionar-se com os seres que o cercam e a realidade em que se integra. Como diria Sartre (1964, p.44):

a linguagem não é um fenómeno acrescentado. Originalmente ela é o estar à disposição dos outros, isto é, ela permite que o indivíduo experimente a sua subjectividade ao opor-se ao outro ou ao tornar-se objecto do outro. A linguagem faz parte da condição humana; ela surge como condição do ser, sempre que o ser se defronta com um outro ser. Existindo, estando no mundo, o ser exprime-se através da linguagem. A linguagem é a manifestação do ser que existe.

Reiteramos, pois, a ideia, sustentada no Quadro europeu comum de referência para as línguas, de que "é objectivo central da educação em língua promover o desenvolvimento desejável da personalidade do aprendente no seu todo, bem como o seu sentido de identidade, em resposta à experiência enriquecedora da diferença na língua e na cultura” (CE, 2001, p.19).

Em termos pedagógico-didácticos, embora a gramática procure fornecer uma base sólida ao ensino das línguas vivas, impõe-se viabilizar a descoberta das virtualidades e potencialidades da língua; esta dimensão comunicativa permanece a par do conhecimento das unidades ou das regras constitutivas. Procuramos, então, orientar a nossa acção, tendo presente que não devemos esquecer a importância 
do conhecimento da língua em uso, numa determinada comunidade, numa determinada época;

$\square$ do reconhecimento das suas potencialidades enquanto instrumento de comunicação;

$\square$ da abordagem de definições precisas e verificáveis da sua utilização.

Mantemos, em paralelo, sempre presente, que a linguagem é, antes de mais, a manifestação, a revelação do ser íntimo e do lado psíquico que nos une ao mundo e ao semelhante. Nesse sentido, procuramos também não esquecer as funcionalidades da língua.

Em síntese, neste simpósio, pretendemos não só focarmo-nos na relação subjectividade/ intersubjectividade, passível de ser vivenciada pelo recurso à língua, mas também no uso da língua oralidade, escrita, leitura - com vista à promoção de uma abertura ao mundo real e ao mundo imaginário que no interior de cada ser existe, escondido e latente. Importa, portanto, não esquecer que:

a língua materna funciona como um cordão umbilical que mantém a ligação do indivíduo ao grupo, à comunidade que criou as condições necessárias à aprendizagem e, concomitantemente, o leva à descoberta do mundo e ao assumir de uma determinada forma de o ver de nele se manter. (Lamas, 1992, pp.134,135)

\section{A língua na educação / a língua para a educação}

Começamos por nos questionar sobre formas de, em contexto educativo, tirar partido da dimensão ontológica da língua para a descoberta do ser, para a sua integração no meio, para o relacionamento com o outro, para a construção do conhecimento. Lembramos Sartre (1943, p.440), que, ao retomar as palavras de Heidegger "je suis ce que je dis”, declara: “je suis langage”. Reiterando esta ideia, convocamos também Benveniste (1976, p.59: "É na e pela linguagem que o homem se constitui como sujeito; porque só a linguagem funda realmente na sua realidade, que é a do ser, o conceito de 'ego'."

Cientes de que "o ser não vive por si, não vive isoladamente; ele é, bem ao contrário, o resultado de uma rede de influências intrínsecas que, por sua vez, se irão interceptar e determinar novas influências e, consequentemente, novas estruturas" (Lamas, 1992, p. 105), importa, pois, em sala de aula, criar condições para que a interacção aconteça, para induzir o aluno a fazer uso da língua de forma reflectida, analítica e crítica, desenvolvendo competências comunicativas e linguísticas, isto é, potenciando a comunicação fluente e enfatizando o uso correcto da língua.

O desenvolvimento da pedagogia de cariz dialógico, ao longo das últimas décadas, tem demonstrado que as teorias construtivistas e conectivistas são fundamentadas no uso da linguagem e da comunicação; o conhecimento é construído através de processos colaborativos acionados pela exploração e pela interacção, presencialmente e a distância. Procura-se, pois, um contributo para a organização das aprendizagens, de forma não só a implicar o aluno, mas também a levá-lo a tornar-se autónomo, deixando de ser um mero receptáculo do conhecimento, isolado e passivo, para se assumir como participante (inter)ativo, comunicativo e reflexivo.

Nessa organização das aprendizagens, contempla-se a combinação de actividades que potenciem a comunicação fluente e outras que apelem ao uso correcto da língua - tarefas de precisão para apoiar outras de fluência e vice-versa.

\section{Abordagem comunicativa}

A comunicação ganha um sentido profundo na vida do ser humano e, por isso, no ensino da língua, a abordagem comunicativa, ao centralizar o processo de aprendizagem no aluno, propicia-lhe oportunidades de autoconhecimento, de autonomia na sua integração em contextos, sejam eles de que natureza forem; remetemos, entre outros, para o escolar/académico, o cultural, o social, o socioeconómico, em evidência nos artigos que integram o simpósio.

O suporte a que se apela, entre a fluência e a correcção, já estava presente nas preocupações manifestadas pelo grande pensador e teólogo Alexandre Vinet (1829); no seu ofício de professor, ele pugnava por pôr os seus alunos em contacto com os melhores mestres da língua e do pensamento; a sua obra Chrestomathie française, com 3 volumes, foi durante muito tempo, considerada um modelo do ensino da língua francesa. $O$ apelo que deixava aos alunos e que, hoje, convocamos, ao reflectirmos sobre o ensino da língua, salienta a dialética aludida:

Il s'agit d'apprendre notre langue à fond, d'en pénétrer le génie, d'en connaître les ressources, d'en apprécier les qualités et les défauts, de nous l'approprier dans tous les sens (...). Mais étudier une langue, ce n'est pas seulement se donner l'habitude, l'instinct de cette langue : c'est apprendre à s'en servir avec connaissance de cause. C'est étudier, jusqu'à un certain point, les choses dans les mots, l'esprit dans les signes de ses pensés, l'homme dans sa parole. (...) Toute langue est un phénomène naturel digne d'être étudié, et renferme des trésors pour la réflexion (...). (Vinet 1829:157)

Ao comunicar pelo recurso à língua materna e/ou a outra língua alvo de estudo, o aluno vai dominando a estrutura e as regras, usando-a(s) de forma apropriada e adequada às diferentes situações, entendendo-a(s) na(s) sua(s) especificidade(s), na(s) sua(s) funcionalidade(s).

A abordagem comunicativa defende 0 acto comunicativo como unidade básica da língua e o mais importante, nessa abordagem, passa a ser a compreensão e o significado. O valor atribuído às competências comunicativas sobrepõe-se ao conferido às competências linguísticas; todavia, não as minimiza, já que o desempenho, conseguido pelas primeiras, induz ao domínio das segundas.

Para isso, o ensino da língua desencadeia um processo de aprendizagem contextualizado, situações reais nas quais os alunos estejam implicados; situações que despertem o seu interesse e os motivem para procurar o que sentem poder ser necessário à construção do(s) conhecimento(s) em que estão implicados; focam o sentido, constroem conceitos, na e pela interacção com $o(s)$ outro(s). Para que a procura seja bem sucedida, para poderem dar a conhecer os resultados do seu trabalho, em simultâneo, esmeram-se na aprendizagem da língua, na 
sua estrutura, nas regras que levam ao uso correcto e adequado da mesma.

\section{Da transversalidade à inter/transdisciplinaridade}

A transversalidade da língua está associada ao desenvolvimento de competências comunicativas que levam à compreensão da(s) realidade(s), seja decorrente da interacção do sujeito com essa(s) realidade(s), seja através da leitura de textos que a(s) foquem.

A língua como meio de comunicação induz à (re)construção de conhecimentos pelo uso efetivo e competente da língua em contextos reais de comunicação, através da realização de tarefas e projetos integrados nas áreas em que os/as estudantes desenvolvem os seus estudos, em contextos culturais com os quais se identificam, em contextos sociais que os condicionam ou desafiam.

A operacionalização da língua induz ao desenvolvimento de competências essenciais e, como vimos, requer uma abordagem transversal do seu ensino, relacionando-o com o das restantes áreas curriculares, disciplinares e não disciplinares; daí a necessidade do enfoque interdisciplinar, contribuindo este, quer para o desenvolvimento de competências comunicativas, quer pelo contributo aportado pelas diversas áreas à proficiência da língua, independentemente do uso que lhe é dado e que implica o recurso a

- $\quad$ vocabulário adequado ao tema em evidência;

- terminologia própria da(s) área(s) do conhecimento em causa;

- $\quad$ estruturas frásicas que facilitem a percepção da mensagem pelo receptor;

- marcas culturais próprias do contexto;

- $\quad$ entoação apropriada ao propósito da comunicação.

As práticas conducentes à operacionalização da transversalidade da língua promovem, com efeito, o desenvolvimento quer de competências comunicativas, quer de competências linguísticas,

- que potenciam

- a compreensão na/pela leitura e

- a correcção na produção escrita;

- que apostam, de forma clara,

- na promoção do trabalho colaborativo e

- na rentabilização das áreas curriculares não disciplinares.

Cientes de que, por vezes, as disciplinas se fecham e não se comunicam umas com as outras, apresentando os fenómenos fragmentados, não facilitando o acesso a uma concepção do seu todo (Morin, 1997), questionamos, pois, nos trabalhos desenvolvidos, o valor acrescido de uma praxis pedagógico-didáctica implementada pelo docente, sustentada por um trabalho colaborativo e interdisciplinar que ajude o aluno a percepcionar o(s) conhecimentos(s) que (re)constrói ao longo da sua caminhada escolar/académica, não de forma compartimentada, mas no seu todo, na complexidade da sua estrutura, através de enfoques que permitam a apreensão global das problemáticas abordadas e o estabelecer de pontes entre a sua essência e a realidade.

Dessa rede estabelecida, quer entre as áreas de conhecimento convocadas, quer entre estas e os contextos, emerge a imprescindibilidade de termos sempre presente, no planeamento do ensino da língua, a transdisciplinaridade. Com efeito,

Para transitar por essas áreas, o pesquisador precisará, num primeiro momento, contextualizar cada um desses conceitos lá na sua área de origem, para depois trazê-los para sua área de interesse, submetendo-os possivelmente a um processo de ressignificação. Terá com isso a possibilidade não só de enriquecer sua pesquisa, iluminando-a com a contribuição de outras áreas, mas também, por um processo de realimentação, enriquecer as áreas de origem, confirmando ou rejeitando as informações que foram usadas. (Leffa, 2006, p.43)

É a visão aportada pela transdisciplinaridade que nos leva a partir da realidade em que o aluno se integra, do seu relacionamento com o contexto que o envolve, das experiências vivenciadas na interacção não só como o(s) outro(s), mas também com o mundo em que vive com o(s) mundo(s) com os quais entra em contacto através das leituras que faz, das relações que mantem.

Vemos, assim, o ensino da língua não centrado nela, mas a partir do mundo que ela retrata, que ela (con)figura, que ela modeliza. Tomando como ponto de partida determinada realidade, determinado objecto, usamos a língua, pelo recurso a uma ou mais áreas do conhecimento, para chegar à compreensão dessa realidade, desse objecto. Pelo uso da língua (mediadora entre o sujeito e o objecto), não só construímos o conhecimento - não compartimentado, mas na sua complexidade -, como descobrimos as potencialidades da língua para

- exprimir os nossos pensamentos e sentimentos, descobrindo as nossas capacidades e limitações

- comunicar/interagir, entrando em contacto com $\mathrm{o}(\mathrm{s})$ outro(s) e com o mundo, modelizando-o;

- construir conhecimento.

A complexidade do ser humano faz com que as suas expectativas sejam diversas e variadas. Na verdade, ao recorrer à leitura, o sujeito leitor pode ter em mente vários objectivos; por outro lado, na sua mente, muitos conhecimentos estão armazenados e, na sua memória, muitas vivências se encontram em reserva. Contudo, por muito diversificados que possam ser os objectivos a que se propõe, tal como já referimos, o fim último será o alargar dos conhecimentos, o que implica uma transformação do sujeito-leitor, em diálogo com o objecto (o texto e o seu emissor), isto é, envolvido no acto de comunicação, confrontado consigo mesmo, atualizando os conhecimentos já assimilados, revivendo momentos do passado que a memória guardou, projetando-se no futuro, para o qual se prepara no âmbito da educação formal, não formal e informal.

Nunca será de mais referir que, enfatizando o desenvolvimento de competências comunicativas, não deixamos, contudo, de focalizar o uso correcto da língua, levando à reflexão em contexto educativo sobre questões linguísticas, sendo que o/a professor/a assume a função de orientador/a, facilitador/a, promovendo desenvolvimento da proficiência linguística.

Lembremos, entre os muitos objectivos que a leitura pode visar, alguns dos mais comuns perseguidos em situação escolar/académica:

$\square$ pesquisar informações pertinentes para o(s) estudo(s) empreendidos; 
recolher informações relativas a determinada área do saber;

aprofundar o conhecimento sobre um assunto específico;

organizar as informações em função das problemáticas abordadas;

desenvolver a capacidade para a discussão dos problemas emergentes;

estruturar as ideias a partilhar;

adequar a estrutura linguística aos propósitos comunicativos;

sustentar solidamente posições assumidas; argumentar pontos de vista com sustentação;

estabelecer pontes entre o(s) contexto(s) reais confrontados e a(s) área(s) de conhecimento em estudo.

Um aspecto importante a ter em conta numa situação de aprendizagem é a escolha do texto de acordo com o objectivo que se pretende atingir. A adequação é, sublinhamos, uma estratégia indispensável em didáctica. Mas, mais uma vez, podemos afirmar que o facto de o objecto de estudo assumir estatutos diferentes, que desencadeiam climas também eles diferentes, permite que o leitor saia transformado, saia enriquecido. A versatilidade de estatutos, a multiplicidade de situações, a mutação dos climas desencadeados são, quando planeados e bem articulados, factores de enriquecimento.

Poderemos falar respectivamente de competências cognitivas e referenciais, de competências textuais e discursivas e, ainda, de competências ético-estéticas subjacente ao relacionamento com o(s) outro(s). Interagindo e complementando-se, estas competências concorrem para que o leitor atinja os objectivos que se propõe ao comprometer-se no acto da leitura.

\section{A leitura gnoseológica}

O 'estar pronto' para a procura, para o 'desbravar' dos mecanismos textuais (sejam eles quais forem), no sentido de construir um sentido, exercitam a mente, ativam a perspicácia intuitiva para o entendimento da textualização e preparam o sujeito-leitor para qualquer situação de leitura. Quanto maior e mais variada for a prática da leitura, tanto menos difícil será o defrontar-se com qualquer tipo de estrutura textual, mesmo que se trate de um texto diferente daqueles com que o sujeito-leitor está acostumado a lidar.

Só pela prática contínua da leitura, o sujeito se exercita e desenvolve as competências. O deparar com dificuldades e/ou com obstáculos não deve fazê-lo desistir, isto é, pôr de lado o objecto que pretende apr(e)ender, a intenção de construir algo de novo. Os obstáculos, tal como na vida em geral, podem servir de estímulo; são eles que levam, muitas vezes, o leitor, a procurar estratégias novas, diferentes, para ultrapassar as dificuldades que vão surgindo.

O exercício pedagógico denominado por leitura metódica consiste em aplicar, no tratamento do texto - na decifração -, as noções trazidas à textualidade. E, para cada situação, para cada tipologia textual (de acordo com as suas micro, macro e superestruturas) os caminhos a seguir serão, por certo, distintos. Compete, aí, ao professor, agir e transformar aquilo que poderia ser negativo em positivo.

$E$, já que o ponto de partida é um objecto verbal e que ele se constitui em medianeiro, os conhecimentos construídos variam de sujeito para sujeito, o real apr(e)endido é também ele visionado de formas diferentes de acordo com aquele que o apr(e)ende; o conhecimento construído será, consequentemente, um conhecimento distinto dos outros; os horizontes mais rasgados num do que nos outros.

Retomamos, aqui, a ideia da liberdade que deve presidir à leitura; como Sartre (1964: pp.59,60) diz "l'écrivain en appelle à la liberté du lecteur pour qu'elle collabore à la production de son ouvrage. (...) Le livre ne sert pas ma liberté: il la requiert." liberdade num sentido múltiplo - liberdade para escolher a forma adequada de leitura, liberdade para selecionar passagens, deixando umas de lado, retomando algumas delas depois e, ainda, liberdade de associar os signos entre si e os signos aos conhecimentos já adquiridos, às vivências anteriores, variando deste modo as previsões que se fazem a partir dos indícios deixados pelo escritor e, consequentemente, partilhando com ele o acto de criação.

Nessa partilha, constroem-se os sentidos múltiplos que a ambiguidade provoca, deixando esta que os significantes se renovem, através dos significados múltiplos que as associações, acima referidas, originam. Propõem-se, portanto, leituras diversas que permitam um trabalho envolvente e produtivo. Incidindo sobre diversos textos e relacionando-os com experiências reais vivenciadas em contexto, elas poderão complementar-se e oferecer uma visão mais rica e profunda do acto de ler encontro leitor/texto - e nesse encontro, as potencialidades do leitor serão, por certo, ativadas e conhecidas, dando os seus frutos.

Enfim, cada sujeito define-se como ser único e diferente dos demais, desenvolvendo uma forma de estar no mundo particular, uma identidade própria. O fim último da leitura é, pois, de natureza gnoseológica; se bem que diversificada, a construção de conhecimentos é uma realidade, situando-se estes em áreas também elas diversificadas - a da cultura, a da língua e a da estética. $\mathrm{O}$ resultado não pode deixar de ser o enriquecimento do sujeito leitor, o alargar dos seus conhecimentos, uma mais equilibrada personalidade, um melhor relacionamento com os outros e, portanto, uma mais consciente inserção no mundo.

Duborgel (1995, p.289), falando da imaginação, confere-lhe o poder de sustentáculo da leitura do mundo - original e criativa: “(...) poder humano de retomar em conta o universo numa forma outra, de o representar e recriar como totalidade e unidade (...) imagem complexa da dramática humana (...) os emblemas da nossa 'realidade'”. O contínuo (re)inventar da realidade reveste-se de um carácter transversal ao processo evolutivo do ser humano - a forma como vê o mundo, como o organiza, como o pensa e como o sistematiza.

\section{A escrita - como perspectivá-la neste contexto?}

Concentrámo-nos, até aqui, no recurso à língua para a (re)construção do conhecimento, tendo sido dado especial relevo às funções que a leitura desempenha. Para 
avançar para a escrita, importa questionar a forma de organizar as ideias e estruturar a sua apresentação. A escrita exige a elaboração de um roteiro que contemple a natureza e intencionalidade, a forma e a finalidade da comunicação que se pretende manter.

Há que ter em conta que o campo de experiência do emissor é usualmente diferente do campo de experiência do receptor; é essa diferença que leva o emissor a tomar decisões no que concerne a comunicação das ideias, dos conhecimentos em causa. A abordagem comunicativa está também, aqui, presente; se, por um lado, são as motivações do emissor que determinam a intencionalidade da comunicação, por outro, é o perfil do receptor, as circunstâncias em que este se encontra, que levam o emissor a escolher a forma de comunicar.

Discutir, reflectir, contrapor, articular, expor, ... são formas diferentes de dizer as coisas, de apresentar as nossas ideias, de dar conta das posições que assumimos relativamente ao outro, ao mundo, aos conhecimentos (re)construídos através das interacções mantidas, das leituras assumidas como fonte, como ponto de partida para a nossa escrita.

Uma vez que, neste artigo, sustentamos o ensino da língua na sua dimensão ontológica, dando especial atenção ao perfil do aluno, sublinhamos a importância do incentivo à (auto)biografia, pelo recurso a estratégias diversificadas, reconhecendo que ela pode ser concretizada de diferentes formas - pelo diário de aula, pelo blogue, pelo portfólio. Estamos convicta da importância da escrita para um maior envolvimento do aluno na aprendizagem, para autodescoberta do 'eu', das suas potencialidades e limitações, viabilizando dessa forma não só a (auto)avaliação e a promoção da meta-cognição, mas oferecendo complementarmente a oportunidade de descobrir as melhores vias a seguir, para a produção de uma escrita que contemple as diferentes intencionalidades comunicacionais, que dê respostas à complexidade do 'eu', permitindo-lhe exprimir-se, relacionar-se, construir e partilhar conhecimento, desempenhar tarefas.

\section{Conclusão}

Como forma de conclusão, sustentamos a ideia de que o ensino da língua, de acordo com a abordagem comunicativa, leva a criar um processo de ensino aprendizagem centrado no aluno, baseado em funções comunicativas, estimulando-o a descobrir a sua maneira de ser e estar, as suas potencialidades, a interagir com o(s) outro(s) e com o mundo, organizando as informações que vai recolhendo, veiculando as suas ideias, aprofundando e reconstruindo os conhecimentos.

As necessidades comunicativas e expressivas são, como houve oportunidade de problematizar, o ponto de partida que leva à compreensão do mundo e do saber, ao questionamento orientado da estrutura da língua, promovendo o seu aperfeiçoamento, a comunicação, a expressão oral e escrita, a leitura.

Defendemos a necessidade de conhecer o aluno para, a partir da sua realidade e das suas vivências, organizarmos experiências de aprendizagem, recorrendo a estratégias cognitivas, metacognitivas e sócio-afectivas, com a realização de tarefas, actividades, projetos do interesse e/ou da necessidade do aluno. Por isso e ciente de que a leitura gnoseológica permite ao ser humano a construção de conhecimentos, a apreensão do real, a consolidação dos saberes, o rasgar de horizontes, a inserção do 'eu' no mundo que o rodeia, É para isso que apontam os outros artigos que integram este simpósio. Reconhecemos, que a perspectiva dialógica e interactiva induz a um contínuo aperfeiçoamento da escrita.

\section{Referências}

Benveniste, (1976). O Homem na Linguagem. Lisboa: Editora Arcádia.

Duborgel, B. (1995). Imaginário e pedagogia. Lisboa: Instituto Piaget.

Lamas, E. (1992). O Texto Poético como Objecto Pedagógico - Contributos para a Didáctica das Língua e Literaturas Maternas. Tese de doutoramento. UTAD, Vila Real: Portugal.

Lamas, E. (2000). Dicionário de Metalinguagens da Didáctica. Porto: Porto Editora.

Lamas, E. (2011). Para uma Aprendizagem Contextualizada, Activa e Significativa. Actas del XI Congreso Internacional Galego-Portugués de Psicopedagoxía (pp. 4705-4715). Coruña: Universidade da Coruña.

Lamas, E. (2013). Língua e cultura, a afirmação e cada um(a) - a identidade de um povo. Atas do XII Congresso Internacional Galego-Português de Psicopedagogia (pp. 4777-4793). Braga: Universidade do Minho. Disponível em http://webs.ie.uminho.pt/xiigp/at10.pdf acedido em janeiro de 2014.

Leffa, V. J. (2006). Transdisciplinaridade no ensino de línguas - A perspectiva das Teorias da Complexidade. In Revista brasileira linguística aplicada, vol.6, n.1, pp. 27-49. Disponível em http://www.scielo.br/scielo.php?script=sci_arttext \&pid=S1984-63982006000100003 acedido em julho de 2015.

Conselho da Europa. (2001). Quadro europeu comum de referência para as línguas: aprendizagem, ensino, avaliação. Porto: Edições Asa.

Morin, E. (1997). Réforme de pensée, transdisciplinarité, réforme de l'Université. In Motivation, n.24, 1997. Disponível em http://ciret-transdisciplinarity.org/bulletin/b12c1.php acedido em março de 2011.

Sartre, J.-P. (1943). L'Être et le Néant. Paris : Editions Gallimard.

Sartre, J.-P. (1964). Qu'est-ce que la littérature? Paris : Editions Gallimard.

Vinet, A. (1829). Chrestomathie française (Vol. 1, 2, 3). Basel. 